\title{
Stacy Klein
}

\author{
in conversation with Maria Shevtsova
}

\section{On Double Edge Theatre}

Founded in Boston by Stacy Klein in 1982, initially as a women's theatre, Double Edge moved to Ashfield in Massachusetts in 1997 to the rural complex now known as the Farm Center. The Farm comprises rehearsal rooms, living quarters, technical workshops, an ante-room to welcome and dine spectators, a magnificent loft-like performance space, and acres of land with trees and a pond. The whole is set against a soft New England landscape, and the Farm's grounds are the almost idyllic environment for the summer promenade spectacles that, like its more formal productions indoors, provide a focus for locals, sustaining their sense of community and even the myth of community nurtured historically in these parts. In this conversation of 13 and 14 November 2009 (which was extended in August 2010 after The Firebird, the summer spectacle of that year), Stacy Klein discusses how local people support Double Edge and otherwise form a long-term relationship with the company, now visited by spectators as well as practitioners from further afield - Klein's Polish teachers and mentors among them. Double Edge is a devising company, working with improvisation and free association to form strong visual imagery through pronounced physical movement, which also involves circus skills. This, together with a frequently startling use of objects, is the basis of their magical realism (notably in the unPOSSESSED of 2004, after Don Quixote), a style developed by the company in its rural retreat, and subsequently combined with the tonalities of grotesque surrealism. The Republic of Dreams, for instance, inspired by the life and work of Bruno Schulz, enters the world of vivid dreams, powerful memories, and nostalgic echoes, the whole evoking an evanescent past into which its agile, versatile performers - some singing, some dancing - tune in, like ghosts absent and present in one and the same instance. The two productions noted here are part of what Klein calls a 'Cycle'-a grouping of works that have evolved over a number of years as separate pieces, some beginning life as a summer show before they grow and link with the other pieces of a given Cycle, which is almost always a trilogy. Gradual, consistent development is key to the company's work, as is its belief in a distinct company ethos, which its trainees are invited to share. Maria Shevtsova, who enjoyed the Farm's hospitality when she talked with Stacy Klein, holds the Chair in Drama and Theatre Arts at Goldsmiths, University of London, and is the co-editor of New Theatre Quarterly.

Maria Shevtsova You went to Wroclaw, in Poland, in 1976 and 1977, and you worked with Rena Mirecka, who worked with Grotowski. Did you intend to go to Rena?

Stacy Klein No, I actually went with a bunch of people who mostly still work in the American theatre. We went on this Kosciuszko Foundation trip to see Polish theatre, and I was the youngest one there because it wasn't really for college students, but I applied and went because I had heard of Grotowski. This was in 1976. I saw something like thirty-six - if not fifty-eight - plays in six weeks all over the country. I worked with [Henryk] Tomaszewski for a week. It was great. But, later, on the second day working with Rena, Antek Jaholkowski, and Sigmund Molik, I broke my collarbone and ended up in a Polish military hospital. I then had to go back the next summer because I never really got to work with them. So, I went back in 1977, specifically to work with Rena and Sigmund, both of whom I ended up bringing to the United States to Double Edge almost a decade later. After that I also went to Italy to work with Rena.

So you've been connected with her all your life. She's been here, at Ashfield, this summer [2009]. 
Yes. It was the first time we saw each other in twenty years, and it was really amazing. She was here for a month and we really connected, and we're going to continue working together in one way or another. She's really, really special.

Rena appears to be the formative influence in your development as an artist. What would you say you got from her that you were able to appropriate, to make your own, and to grow from?

Respect for the actor and respect for a practice. Respect has to do with an attempt at understanding and a desire to challenge, to recognize potential.

You said yesterday that you had learnt many things from Rena as an actor, but that you wanted to go and study with a director. You went to Eugenio Barba in Holstebro in 1985. Could you elaborate on that for me?

Well, I just wanted to study directors. It wasn't necessarily Barba - when I went there, I hadn't seen his performance work but I enjoyed the process that he was working with when I saw it in Canada. Jacques Chwat, a collaborator of Grotowski, was brought in as a guest artist at Tufts, where I was a graduate student, and he opened up a new world for me. First, he gave me [Bruno] Schulz's Sanatorium Under the Sign of the Hourglass for my birthday, a book that has changed my life. He also said, 'You have to go to Canada to Eugenio Barba's symposium.' And I was, like, 'Who?' I asked Barba if I could come, and he replied 'No, no, no ... OK.' He let me come, and after the symposium, he said that I could write my dissertation on him. I thought the work was astute. I went to his performance and it was something that really interested me, although in a different direction from the one I wanted to take. Ultimately, with Rena there was also something different from my work, and this different way of thinking continues today. When you're finding your work, you usually need to disagree with the people who are your mentors.

When I was with Barba, he was using the word 'science'. For myself, rather than science, I might be talking about the 'laws of the theatre' or even the 'ethics'. His approach to research was clinical, and that certainly would fall into the realm of science, in one way or another. I have no opposition to that. Oxyrhincus [Oxyrhincus Evangeliet, 1985], which I saw twenty-six times, is one of my favourite performances, but it's not the way that I see.

You mentioned [Wlodzimierz] Staniewski yesterday. Did you spend time with Gardzienice?

Double Edge collaborated with Gardzienice, beginning in 1986, and produced four of their US tours. They co-produced us in Lublin in 1988, 1997, 2002, and again in 2006. I visited there with some of my lead actors and they visited me; we exchanged a lot of music and built some wonderful and deep relationships. Then, we were supposed to do an expedition together in the Carpathian Mountains in the early 1990s. We started together, but ended up separately. My interest, the Jewish culture, could not be explored in the same way Staniewski was researching the other Mountain cultures. In these past few years, we decided not to work together and just be friends because we've gone in different directions. I think that the work of both companies is rooted in passion and not in form, but what comes out is really distinct. Gardzienice is obviously rooted in music and we're obviously rooted in image.

Maybe it's a cultural thing, or a matter of background, or just individual - how you see as an artist, or how you hear. I think that my interpretation of research is different both from Staniewski's term 'expedition', and from Barba's 'barter'. I'm Jewish and I'm a woman. Maybe the woman is a really important part of my identity and work, because I think I'm more shy about claiming to have an answer to how to deal with other cultures, and I'm not from a dominant culture or a dominating gender. I have a kind of quiet approach to this and maybe it is too quiet.

What I'm seeing through everything you're saying is a very strong link. I don't want to draw lineages and heritages, but I gave a lecture in Wroclaw last week where I talked about the 


\section{Double Edge: a Chronology}

\section{Performances}

Woman's Cycle (1982-1986)

Rites (1982), based on Euripides' The Bacchae

Blood Rubies (1982)

My Sister, In This House (1983)

The Hunger Artist (1983)

Had She Spoken (1984-1985)

A Bold Stroke for a Wife (1985)

Request Concert (1985)

Song Trilogy (1987-1999)

Song of Absence in the Fall of the Ashen Reign (1988)

Song of Songs (1992)

Keter, the Crowning Song (1996)

The Garden of Intimacy and Desire (2001-present)

Relentless (2001-2003)

the UnPOSSESSED (2004), based on Don Quixote by Miguel de Cervantes

Republic of Dreams: under the Sign of the Crocodile (2006), inspired by the life and artwork of Bruno Schulz

the Disappearance (2008), from the story by Ilan Stavans

\section{Summer Spectacle Series}

The Saragossa Manuscripts, by Jan Potoki (2001)

the UnPOSSESSED (2003)

The Master and Margarita, by Mikhail Bulgakov (2004)

A Visit to the Republic of Dreams, based on the writings and art of Bruno Schulz (2005)

The Three Musketeers, by Alexander Dumas (2006)

Magician of Avalon, based on the legends of Merlin and the Knights of the Round Table (2007)

The Illustrious Return of Quixote, based on new chapters and adventures from Don Quixote

by Miguel de Cervantes (2008)

The Arabian Nights, based on Marc Chagall's illustrations for The Arabian Nights (2009)

The Firebird (2010)

\section{International Collaborations since Double Edge's installation at the Farm in 1994}

The US/Latin American Spiral Mirror Project (1996-2001)

The International Consortium for Theatre Practices, in collaboration with Gardzienice (1999-2001)

The Summer Ex-CHANGE project (2002-2004)

The Triangle Project with Charlestown Working Theater, Boston and q-Staff, Albuquerque (1994-present)

Russian Collaboration, with Oksana Mysina and John Freedman (2010-present)

\section{Symposia}

International Artists' Think Tank, Ashfield, Massachusetts (2000)

Intensive Training Consortium with SITI Company and Gardzienice, Ashfield, Massachusetts (2001)

Cervantes 400th Anniversary Symposium with the Five Colleges and Double Edge Theatre, Ashfield, Massachusetts (2005)

Performance Presentation and Schulz Symposium, CUNY Graduate Center, New York (2006)

Art as Healer and Provocateur, Double Edge Theatre's Farm Center, National Yiddish Book Center, Greenfield Community College (2007)

\section{Selected discussions from Double Edge's Conversations series}

Foundations of Laboratory Theatre in the US (2009)

Staging God and Policy (2009)

Approaches to Training (2009)

Bold Women of Theatre, with Rena Mireka (2009)

Fresh Faces (2009)

A Cold War Discussion between Martha Coigney and Anne Bogart

Art and Place: Local, International, Rural Voices (2010) 
studio-laboratory movement radiating from Russia, and about the dust settling. And, of course, afterwards, I thought, 'Dust can also be lethal. It can get into your lungs and kill you.' But the image of dust is important for me because it is subtler than the idea of influence or direct descendants. If I were to draw what strikes me as you speak, it would be this: I can see dust here, dust here, dust here; I can see a pattern emerging. That pattern might take us back to kind of a root source, which is Grotowski, except, of course, that everyone has taken the dust differently, and they have absorbed it, and it has absorbed them, very differently. Your connecting links have all been via Grotowski in some way: Rena, Barba, and Staniewski. You, of course, are very much your own person.

I have no problem with acknowledging my teacher, Rena, at all, and her work was unique and very female, and that was one of the things that drew me to continue to approach her. I am glad that I studied Barba. Staniewski remains more of a brother and colleague than a mentor. One of the founding members of Gardzienice was in the programme that I was in, in Poland, way back in 1976 - Anna [Zubrzycki], who is now at Song of the Goat.

I think we're talking about the theatre and not about life. I like your idea about dust: my 'dust' definitely does not go back to Rena. My 'dust' goes back much further - I think to my Jewish culture. That's one of the things that distinguishes me from all the people we are speaking about. The fact that I'm a woman makes the 'dust' unsettled. I still continue to grapple with the male and Christian notion of life. I believe Rena has a similar struggle. But most of my own research was not in theatre; it was working with people in Kabala and in the study of Midrash, and immersing myself in the artwork of [Marc] Chagall. I would say that this was formative for me.

Before Rena, I was for three years in Little Flags Theatre. Maxine Klein was the director. She was a very conventional director, who was radically political. There were two strands to me. One, I went to Poland because I was looking for that depth, and the other - I worked with Maxine because I was a radical. I think I found a way to merge these two things, but not in a didactic political way, or in a didactic theatrical way.

My meeting with Carlos [Uriona] brought another way to my life - popular theatre, or popular culture. That has really informed a lot of what we are doing now, as well. So, I want to dig into every possible mound of 'dust' that sculpted my being. Although I didn't work with Kantor, I saw The Dead Class [1975] in his basement in Krakow in 1976. Following the performance, Kantor told our group that we were all shit. Seeing that performance was enough for me to consider him one of the primary factors in my theatre. If I could have gone and worked with Kantor, I might have written on him instead of Barba because that performance was probably the most important performance I ever saw. The way he used his background and ethnicity was really important to me. It really spoke to me. To me, his work was not Catholic.

Rena told me, when she was here, that she was really incredibly moved by this whole farm and by what I am doing, and she said that the amazing thing about my work was that it includes life, and all the work that she has seen and has participated in does not. I found that really gratifying - I mean, supergratifying - and I find it to be true.

So, back to Poland and 1976 - we saw theatre that we couldn't see here, even the repertory theatre. I saw One Flew Over the Cuckoo's Nest with [Wojciech] Pzoniak. It was brilliant. Probably, to this day, I have never seen theatre that is so uniformly fertile. So, I hate to limit Poland in those days just to Grotowski, or even just to Grotowski and Kantor. They were the ones who became famous, but all the theatre was just incredible, really vibrant. I think that that experience might have led to my thinking that theatre could be essential and vital and to my ultimate desire to create a living culture and this was more than just the incredible work I did with Rena.

You have emphasized your gender. How does it distinguish you from a male director? 
I know that there's a huge difference. It's not just having to fight with a bunch of people on tour, who tell me that they know better than me about what I should be doing, with lights, with the actors, and so on, ad infinitum.

Do you mean the administrators, the managers these people?

Yeah, the producers. Especially in Central Europe, but I found that, also, in the United States, unfortunately. I think that, when you get to your fifties, you get a new card as a woman. Before that, it's pretty difficult for anybody to believe that you know what you are doing, or that you don't need their help. Double Edge started as a women's theatre and our first work was the Woman's Cycle (1982-1986): the plays were either about women, by women, or the leading artists were women. That was simply because, when I was at Tufts in 1980, there were no women teachers there. I was really shocked, and I wanted to do something that was about women. The women's community was very against what I was doing because it wasn't just a case of 'Here, we're women, hooray'. It was, 'What makes us victims? What makes us behave like victims, and what makes us victimized?' and then I proceeded to work with men to try to explore that together.

The same thing happened with the Song Trilogy (1987-1999). The Jewish community was very upset by Song of Absence (1988) because it dealt with Jews as victims and as victimizers of themselves. So, usually I ended up creating an outsider position. I've come to understand that this is female in some way the idea of exploring the self non-didactically. It's kind of hard because every time you say something about yourself as a woman, people say, 'Are you a feminist?' or start with labels that are so arbitrary and unnecessary.

I find it interesting because in Gardzienice there are more women and fewer men, and in Double Edge there are more men and fewer women. I think that that has to do with the identity of the leader, because maybe people are attracted to their opposites. They want to find what they don't have. I think that's why Double Edge is the way it is. The women find it difficult because I'm their role model, and it's terrible to have a role model when you're working as an artist. You want to run away and say, 'I'm me, I'm me. I'm not you. I don't want to be you, but I want to be you.'

But role models are important. They're like mentors.

Yes, role models are important, like me and Rena. But I don't work with Rena every day. It's very different to have a teacher and go away, taking that teacher's teaching, and finding your own thing. But you can't find yourself when you are faced every day with the person you are modelling yourself after. As an actor, you must be free and wild and more free, one way or another - otherwise the form and discipline will stifle you.

You said that all sorts of popular elements now in your work came with Carlos? Can you elaborate on that?

I can. The idea of play - and this might be another thing that distinguishes me from my mentors, or my 'dust' (I like that word) - has always been really important in Double Edge: the idea of training as play. So, we played in training, but when it came to creating performances, they were more serious. They moved from play to epic. Carlos came with street theatre and masses, and it was at that time that we moved to the Farm. We started the summer performances, really, for ourselves and our training: we were training a lot of people from Central Europe. We started what Philip [Arnoult] calls a 'walkabout', which is taking the audience all around the Farm and having different scenes in the river, in the garden, and so on.

In 2009 it was The Arabian Nights, which was the start of the Chagall Cycle as we based the production on the four stories Chagall illuminated. One time we did The Master and Margarita. The first Summer Spectacle in 2001 was The Saragossa Manuscripts. All of a sudden, we were able to take all of our object work, which had started in training with play, but had ended in pretty heavy imagery 
(steel, trains, slamming) and make it an adventure instead of theatre, or instead of epic. So, this was a kind of merger between Carlos's mass street theatre and my intimate world. Now, this summer, after eight years of doing it, I think we have finally identified our new form. Probably twenty-five people were involved. The indoor version will have six, maybe eight, people.

Tell me about The Firebird, which was your summer show in 2010. Was it also inspired by Chagall? How did you go about preparing it? Unfortunately, I was not able to see it, so I would really like you to give me some details of how it was arranged outdoors and performed.

The Firebird began as a response to Chagall's set and costume designs for the 1945 Metropolitan Opera production of Stravinsky's ballet. This was a very poignant time in Chagall's life, as it was the first art he created after the death of his beloved Bella. Since we began dreaming with Chagall, and decided at the outset to make a Cycle, we have immersed ourselves in his world. So, although the summer performances didn't typically relate to our indoor work, since last year's Arabian Nights we have actually used the summer as a breeding ground for our indoor work. So Arabian Nights was based on Chagall's paintings of four stories in the book of tales, and The Firebird also began with Chagall. Next summer we will work on the Odyssey, using his sixty or so drawings as a departure point.

With The Firebird there were two threads of preparation. The first was work with the core actors of Double Edge - Carlos and Matthew [Glassman], Hayley [Brown] and Jeremy [Louise Eaton], and Adam [Bright]. Carlos and Matthew each created 'etudes' which became the core of the performance, text- and image-wise. Hayley and Jeremy prepared individual motifs, such as Hayley's flying, which later transformed into her portrayal of the Firebird, and Jeremy's mask and dramaturgical work, which turned into her characterization of the Princess. Together they also did an amazing walk down the room, an image that I have only just begun to explore.
Adam, who is also our Technical Director, worked with ladders and other objects, which became the basis of the design.

At the same time Carlos, Matthew, and myself went to do research in Russia, accompanied by our Bulgarian apprentice for translation. We worked with John Freedman, who is also co-writing a book with me, and Oksana Mysina, an amazing Russian stage actress, known in the West for her role in Kama Ginkas's KI. She also happens to be a violinist and has a rock band called Oxy Rocks.

Back to Moscow. We went to do research on Chagall, but what we came back with was totally different. John took us to the place where Chagall had worked, and where the lead actor/director of the Jewish theatre, Solomon Mikhoels, worked before his murder [in 1948]. Supposedly there is his ghost there, but we did not meet him. Then John and Oksana took us to St Basil's church and the design was born. The colour of the cupolas, the shape, the music we heard inside unbelievable. Next we went to their house and saw some old Bilibin journals (oddly named The Firebird), and that was so exciting that we went to the Tretyakov Gallery the next day. The world of Bilibin and Vrubel unfolded before me, and here the concept was born, to find out how the folk tale and folk illustrations were related to a deeper and more intimate world of art and icon. In other words, what is the journey from folk tradition to spiritual quests? In the final tally, this question remained the bedrock of The Firebird, and a new way of working on the summer spectacle.

When it came time to actually create and rehearse, we had many wonderful partners in addition to our ensemble. John came, originally just to write with me, but ended up making the script along with another of our collaborators, Jennifer Johnson from Boston's Charlestown Working Theater. (She also played the role of the Cuckoo, taken from a poem by Anna Akhmatova.) John Peitso, also from CWT, did all the lights, and helped Brian and Scott lead the music, along with Rich Van Schouwen from q-Staff in Albuquerque, who did the musical training 


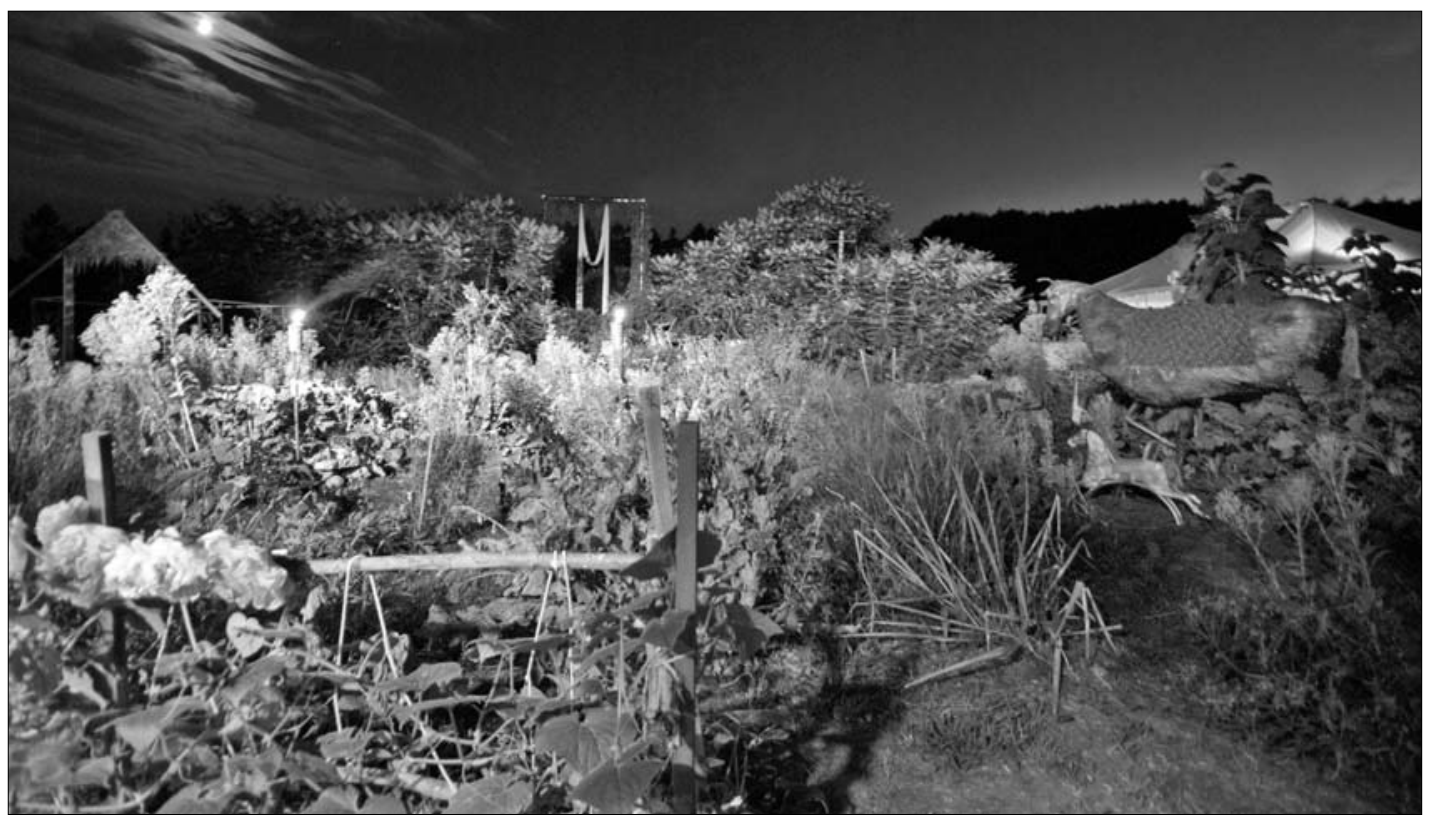

From The Firebird. Photos: Chelynn Tetreault.

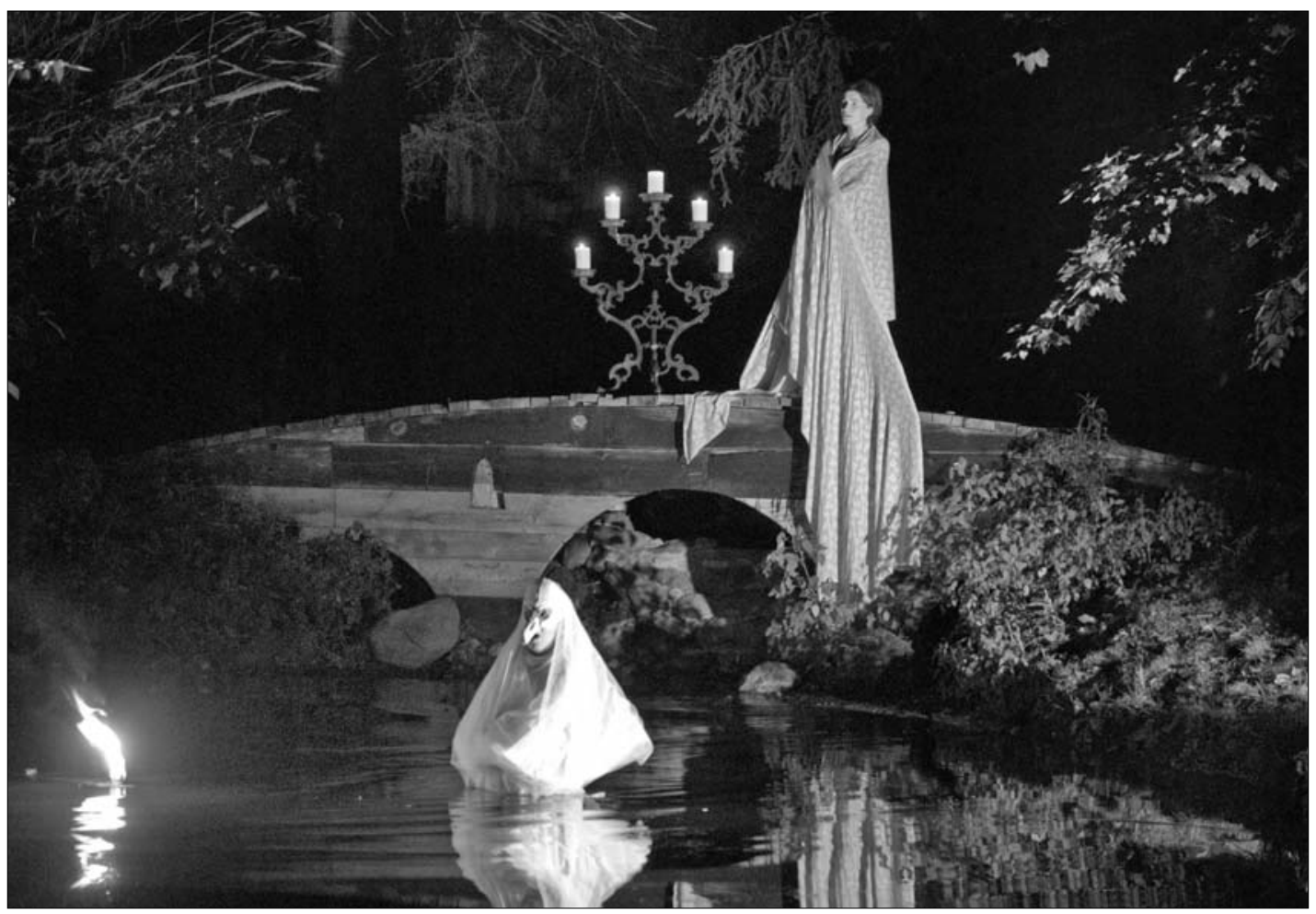

and co-designed with me. And of course, Oksana, who is a really brilliant actor and musician, and just the fact of her 'Russianness' made a huge difference in the tone and the scope of the world we built. It was a very moving summer for our company to work with such great people, but also to build up a core of work that was so strong. I'd decided that this work would focus on the women, particularly Hayley and Jeremy, who were not at all the focus of the Garden Cycle, so this was an important step forward for them.

\section{CAMBRIDGE JDURNALS}




\section{What did it look like?}

It began under a tent as a circus, then moved through a brush-surrounded passage called the silo, which had the Firebird flying over, then to the stream, where the Wolf (Matthew) and Ivan (Adam) met Baba Yaga (Oksana) walking down the stream playing a song on her guitar. Then there was a beautiful garden scene, multilevelled and candlelit, which included a piece of the Stravinsky score. Indoors, in the big barn, was the castle of Koschei, the Deathless (played by Carlos), and it is this scene that we continue to work on - it will undoubtedly be the departure point for the Grand Parade, the first indoor Chagall piece.

A multi-levelled and multi-layered piece, with strong and haunting music throughout, integrated and distinctive flying, tables moving. I think we really got something of the magic of the tale. Floating and disappearances, statues and spells. But most of all, the focus was on the inner journey of liberation from one's own shackles as much as from those that others place upon you.

The end of the performance was pretty spectacular, with Ivan falling into the pond, saved by a flying Firebird, and Koschei walking on water and then disappearing or swallowed by that same water. The audience walked through a forest of icons, painted by Rich and a team of local artists, depicting different versions of Firebird or Phoenix or transforming figures from the performance. The walk and the icons were lit by candles in a wooded path, accompanied by Georgian and Russian choral music. Reflective and beautiful. Finally, the Firebird flies up into the small mountain, with wings burning brightly all the way.

When the moon was out it was unreal people would ask how we did it. The whole merging of nature with art, through the folk, was really very astonishing.

Do you have the same audiences for your summer work as for your indoor performances?

No, although we've trained our audiences. Many people from the summer come to our indoor work who wouldn't have before. And many people are still coming back for the first time since they saw an indoor piece ten years ago because, at the time, they thought the theatre was too weird for them. But now the summer work is also growing with more depth. As Molly Smith (Arena Stage) said, 'You take them in slowly. At first the audience thinks its going to be another typical kids' piece, and then, by the garden scene, you realize you are entering another reality.'

The summer happened because Carlos needed to do grass-roots work and to be connected to the audience, and because of Carlos's and my need to establish a community, or what I call a 'living culture'. We have thousands of people who come in the summer, from all over, but also everyone in this region comes and supports our work. They give us food. It's amazing. Actually, people who love us now give us food all year round. We get bread twice a week from a baker all year round. It's for us and our students, and everybody. The only exchange for that is that they get to come to our performances all the time. They give us between five and ten thousand dollars of bread a year. They advertise for us there. They're really part of us.

Every time we have the Garden Cycle, or an event with food, it's donated by our friends from restaurants in the area. [The Garden Cycle is The Garden of Intimacy and Desire, 2001 to the present, and is composed of the UnPOSSESSED, Republic of Dreams, and the Disappearance.] Our gift bags are filled with donated food so that we can get donations and survive. In turn we publicize all of these benefactors to our audience, so we are living in a barter system. This community has become a real part of the Double Edge experience, and we give back. Our guests stay in the bed-and-breakfasts. I think that somebody tallied that we bring in eight hundred thousand dollars a year to this community because of what we do here.

People fight about which performance is a good performance in the Garden Cycle. Some people say, 'I hate the UnPOSSESSED (2004) and I want to see the other two performances because they are the only two performances.' Others don't like our Republic of Dreams 


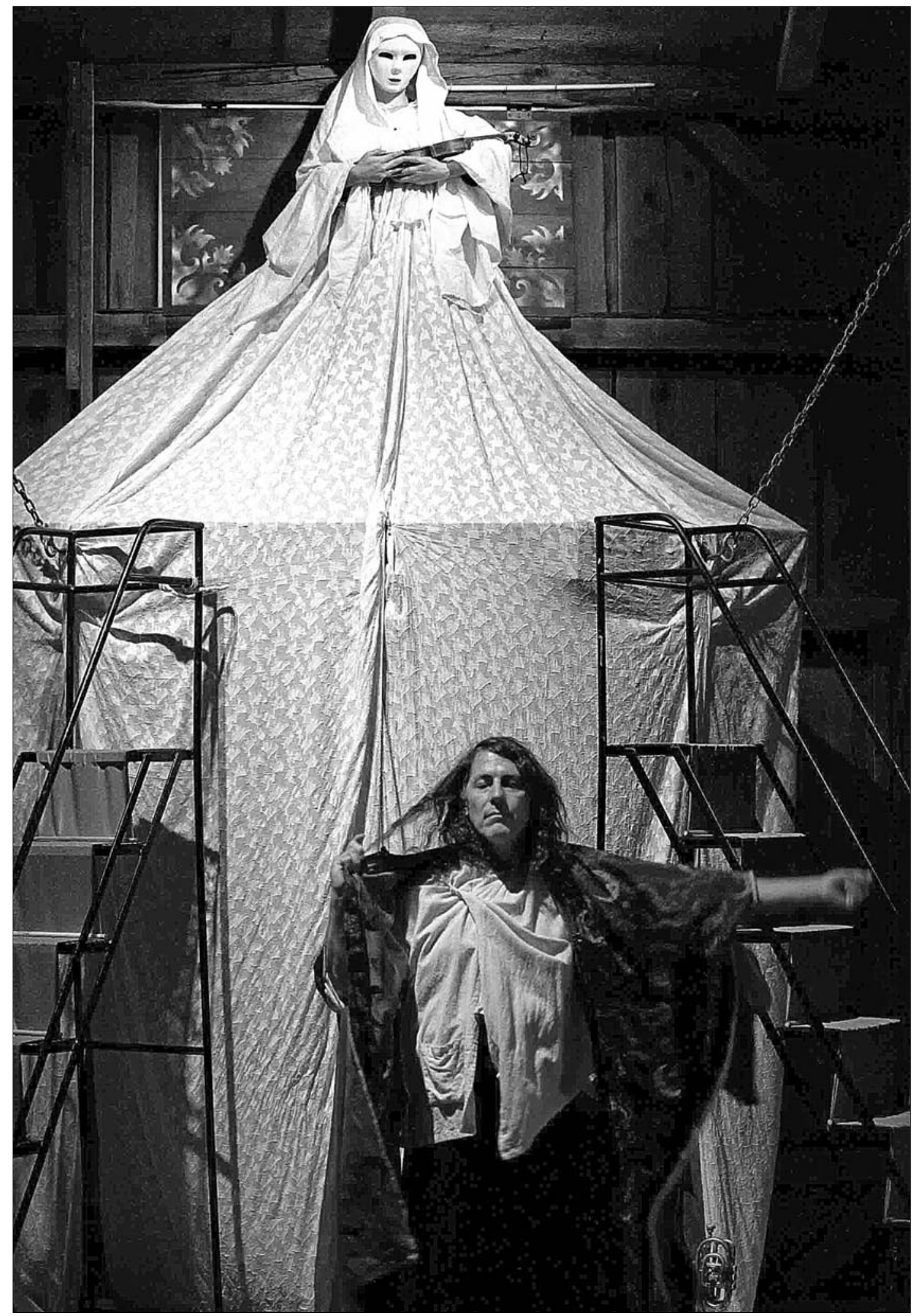

From The Firebird. Photo: Dave Weiland.

\section{CAMBRIDGE JDURNALS}


[Republic of Dreams: under the Sign of the Crocodile, 2006] because it's not linear, which is why I talk about it beforehand. They are very resistant to that, but those people come back to see it again. A woman said to me last night that this was the third time she'd seen it, that it was her favourite Double Edge performance now because she finally understands it.

Somebody else said, 'I didn't understand it. It's my first time, and I feel like I should come back,' and I said, 'Well, it's up to you. You either want to come back and find more layers, or maybe you never want to see it again.' We don't tell people, 'This is the answer. This is the way.' There are different ways to access yourself and the art inside of you - and your culture. Not one of them is 'the' way. That's hard for people to grasp because they think they either have to like everything, or go someplace else. So, we're kind of training people to see that this is a living culture where part of it is something they access, part of it might not be for them, part of it might indeed be the way they want to push themselves.

Ric Zank, who was here a couple of weeks ago, cried throughout the whole of the Disappearance [2008], and I was finally, like, 'Oh, I know what this is about.' It's very American. It's very much about our inability to speak or to do anything over the last eight years.

\section{You mean under George Bush?}

Yes, definitely about Bush, but also about going to Iraq and all of the things that were shoved down our throats, and that we couldn't do anything about. Being silenced. You have to have lived through it to really be touched by that piece. The people who want to produce the piece are those who had been silenced, which of course we all were here, in a way that you and none of you outside will ever really understand. It is a very strange thing, because the mythology of America is so vast and free, and even us radicals from here and all over have bought into that myth. Everybody had their problems in the world I know, but we were really lied to; we knew we were being lied to, silenced, and were unable to do anything.
Even voting didn't help. So, 'silence' is a huge word for me right now. Yeah. The shattering of the myth. So I discovered that. I find it interesting because, for the first time, I have a sort of 'head piece' in the Garden Cycle. The Disappearance is my head and my heart is Schulz [Republic of Dreams], and my body is the UnPOSSESSED, which is based on Don Quixote, the novel by Miguel de Cervantes.

This community that you're building, which is not only a community of actors, musicians, technicians, and so on, but is a bigger community - do you think that that's part of what Rena meant when she said you are 'including life'?

She was talking about the fact that the actors and I have a life; that we don't isolate ourselves from life like she did. She said, 'I never found that and I'm sorry about it, and nobody I know found it.' The kids all live here and there are young children who are a part of it. This means that, by extension, we can include our community in this life. So, she experienced it personally and saw that it allowed something else into the work.

It's air. It's breathing, isn't it?

That's a great word for it.

When did you start doing the Cycle as a cycle, that is, as a trilogy?

In the spring of 2009.

So, before then, they were performed as separate pieces.

Somebody had the daft idea of doing it all together.

You said earlier that you were exploring your Jewish culture. Not everyone in the group is Jewish, presumably.

Almost no one.

How do they adapt and adopt?

When I was doing the Song Trilogy, which was really related to Jewish culture, I would say two-thirds of the group was Jewish and the other third had some relationship to 


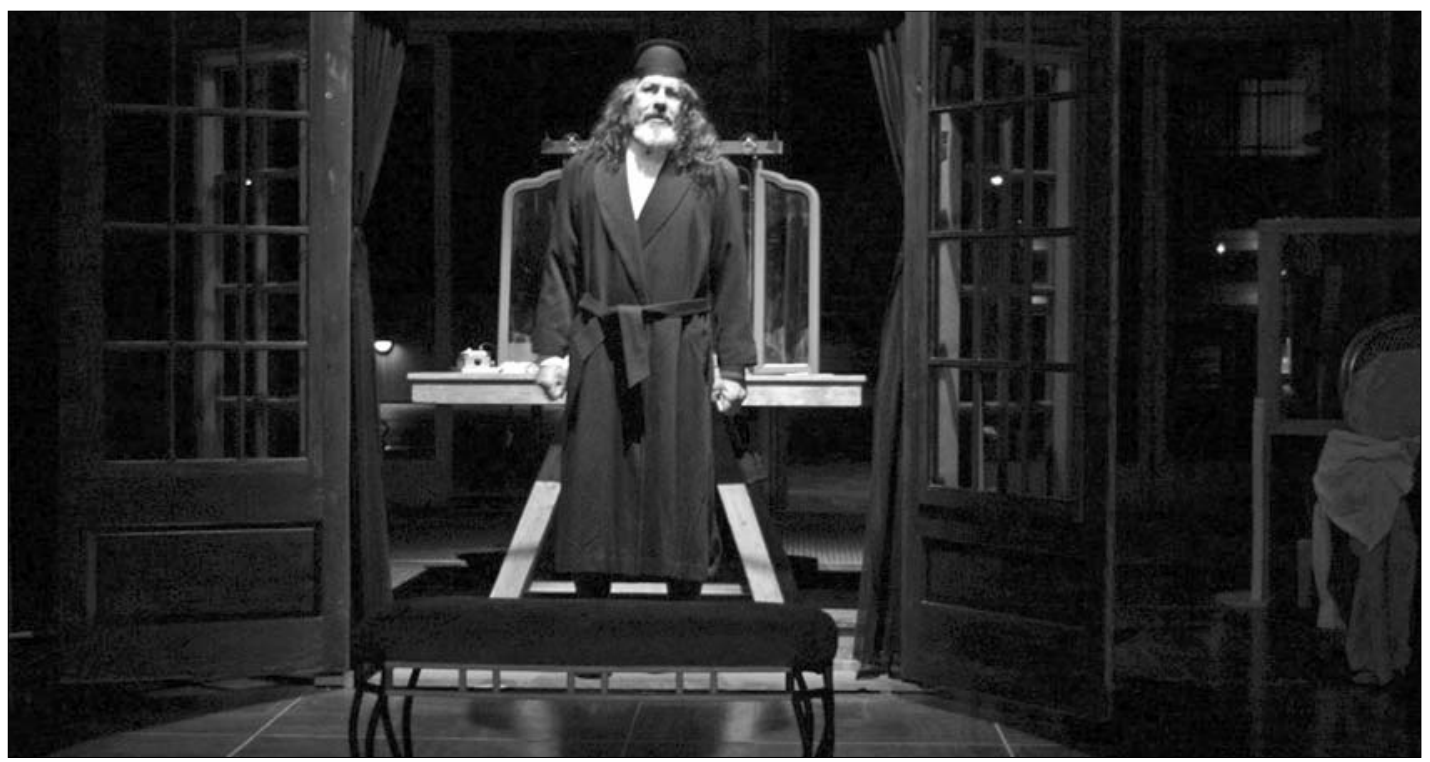

From the Disappearance. Photos: Dans Sheehan (above), Michal Kuriata (below).

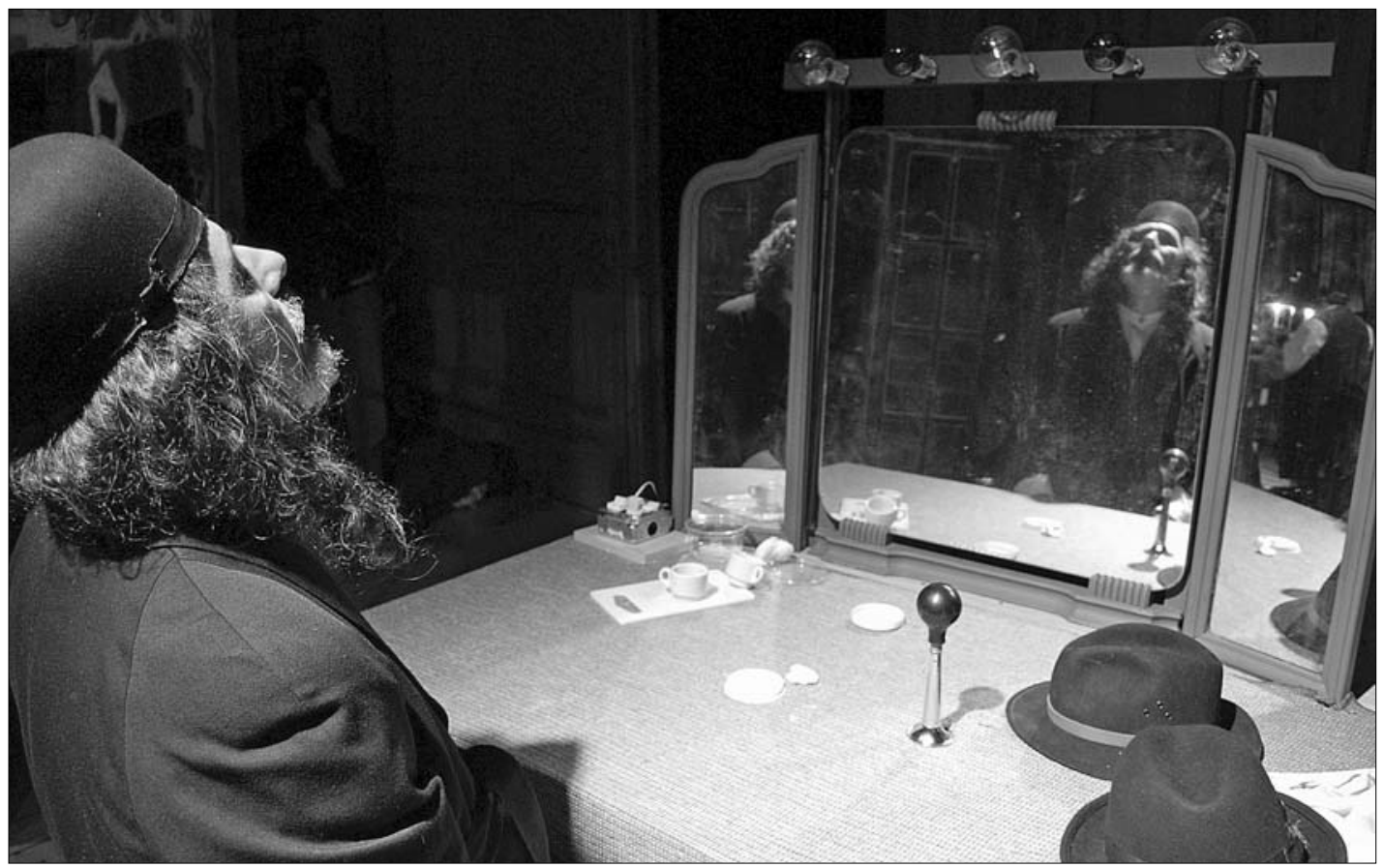

Judaism. They either had one parent who was Jewish, or they themselves wanted to be Jewish, or something. We started working with Charlestown Working Theater and they're Catholics - actually, lapsed Catholics, as everyone I know describes themselves and it became a dialogue of cultures. You can't explore the Jewish culture without exploring the cultures around the Jewish culture. We were working on Don Quixote, and I thought that the rest of the Cycle was going to be more involved with Spanish or Latino influences rather than Jewish things.

Matthew came to Double Edge and fell in love with Schulz. And I said, 'I don't want to deal with Schulz again.' Then, I started reading Schulz again and thought, 'I haven't finished, actually, with Schulz.' And Carlos

\section{CAMBRIDGE JDURNALS}


loved Schulz. Magic realism is an essential feature of both Jewish and Latino culture. The Disappearance was a fluke because, when we were working with Ilan [Stavans, the author of the story the play was based on], we were working on the Mexican refugee situation. Then we ended up working on the Disappearance, because we needed to work on that story. And as I said, it was more because we needed to work on silence than the story itself. We approach our work very personally, each actor and myself. We would never say that we were working on the Jewish part of Schulz. Hayley and Jeremy both created Bianca and Adela in the story and neither are Jewish. We worked with Jacek Ostaszewski, who wrote the music, and he is not Jewish. He's Polish, Catholic. Buddhist, actually.

So, everybody takes their character and makes it from their own experience. All of the people in the Disappearance created those characters before we decided that we were going to work on the Disappearance. Hayley's character is from a different story, and we shaped it and added the whole Merchant of Venice strand, which wasn't in that story. I put The Merchant of Venice into it. Carlos brought in Jacobo Timmerman, who was an Argentinian who had 'disappeared' and then was released [by the military dictatorship] because he was the editor of a newspaper, and the world had protested against his imprisonment. The text of his confession in the performance is from Timmerman's text at the time of his imprisonment, so this is very personal for Carlos. The work for Carlos is not about Bush, it's about the disappearances in Argentina.

Which is where your radical aspect comes in, the political aspect of your work. It's very subtle. It's not agit-prop.

Right, thank you.

And it is part of including life, isn't it?

Yes, totally. I try to teach my students this: you can change the world in a lot of ways.

I was interested in the fact that you called the work that we saw your interns doing this morn- ing an 'etude'. It's Stanislavsky's word. Tell me a little bit about it.

It happened when we started working on the Song Trilogy and creating our own devised work, and each actor had to make a fiveminute proposal. It could be on a story, it could be on some archetype - whatever they were working on. We called them 'studies'. It didn't seem right; it seemed as in 'to study'. So, somebody said 'etude' and it stuck.

Let's go back to what you were saying about exploring culture. I was wondering how you can explore your Jewish culture in the context of a collectivity that might not necessarily share that culture. So, how do you, as a group, explore that? Do the people working with you take it on board as part of something that they can have with you as a shared language? The cultural issue is a difficult one, always.

Carlos is not Jewish, and he explores his culture as I am exploring mine. And that's true of everybody. Some people are not interested in their culture. They explore something else. Maybe their gender is their source point, or whatever. I think the idea is that we all explore our individuality to the fullest, and relate to the group. For me, it's clear what I'm exploring, and it's clear when I go away from that. There were many years when I didn't want to deal with my Jewish culture at all. After the Song Trilogy I was finished. I wanted to explore Carlos's culture more than my own. It wasn't relevant to me, at the time. At the beginning of the Garden Cycle, I was exploring the idea of dialogue how one has a dialogue.

The Jewish dimension came back through Matthew. I wouldn't say that the Garden Cycle is primarily an exploration of Jewish culture for me. It happens that there are Jewish elements in two of the performances. And, even so, that is a line running through, or dust settling, as you would put it, rather than the real nature of those performances, one of which I have already described as American; and the other has to do with the contradiction of being an artist in a violent and ultimately fatal world. 


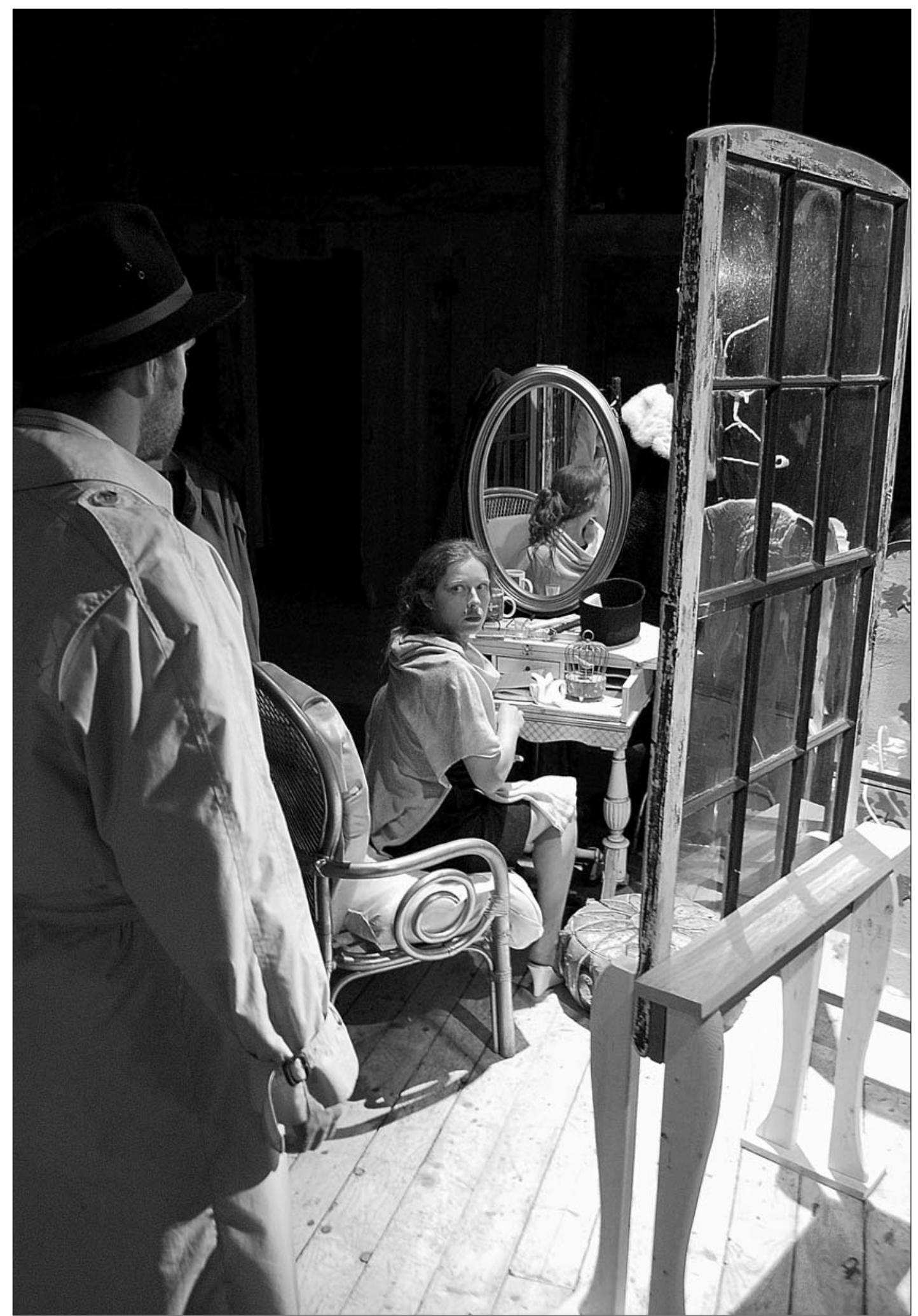

From the Disappearance. Photo: Michal Kuriata.

\section{CAMBRIDGE JDURALS}




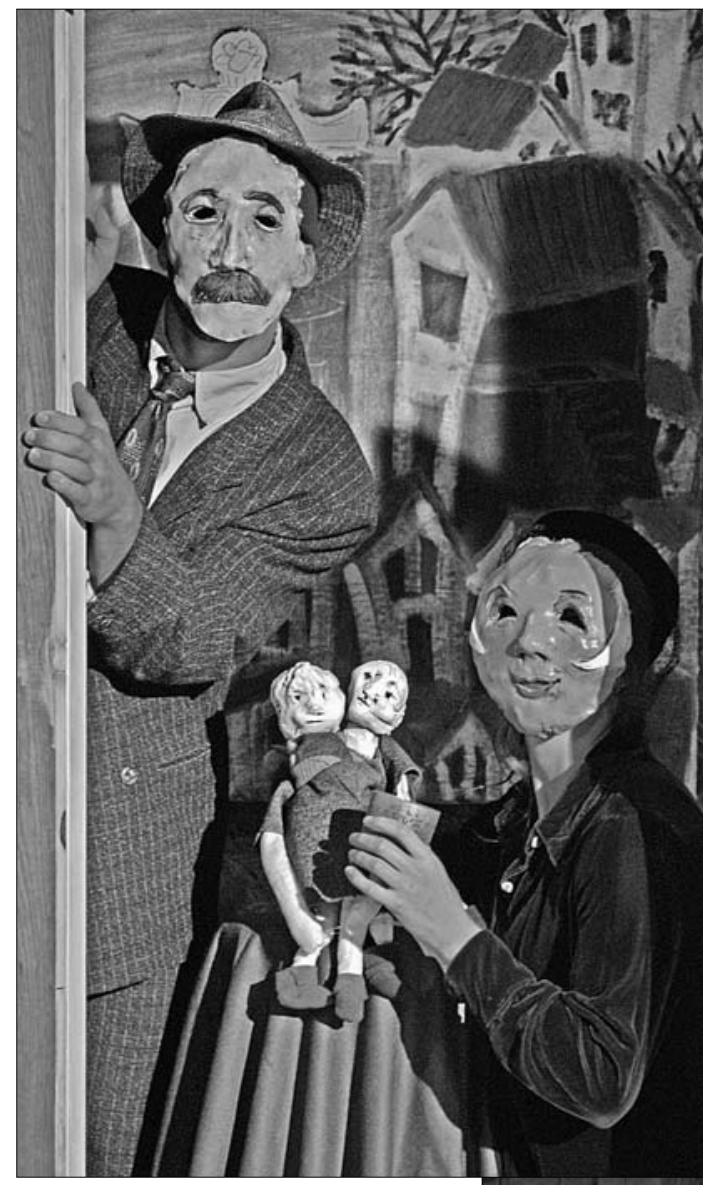

The real exploration for me in this cycle is about dialogue: it's about the relationship between Carlos and Matthew, it's about the relationship with the audience, and it's about living culture; and, I would say, identity and how identity works. Nobody would think that we were exploring culture as a collective. Carroll [Durand] was exploring the Jewish culture in her work as she developed the Garden Cycle. But Jeremy comes from a Quaker background. She was definitely exploring her background and her upbringing because her parents run a non-profit antilandmine company. She grew up in Pakistan because her father and mother were fighting to remove landmines. Her father was in jail for many years here for the peace movement. She was fascinated by the connection between her life and upbringing and the different contextual things we were dealing

From the Disappearance. Photos: Michal Kuriata. 


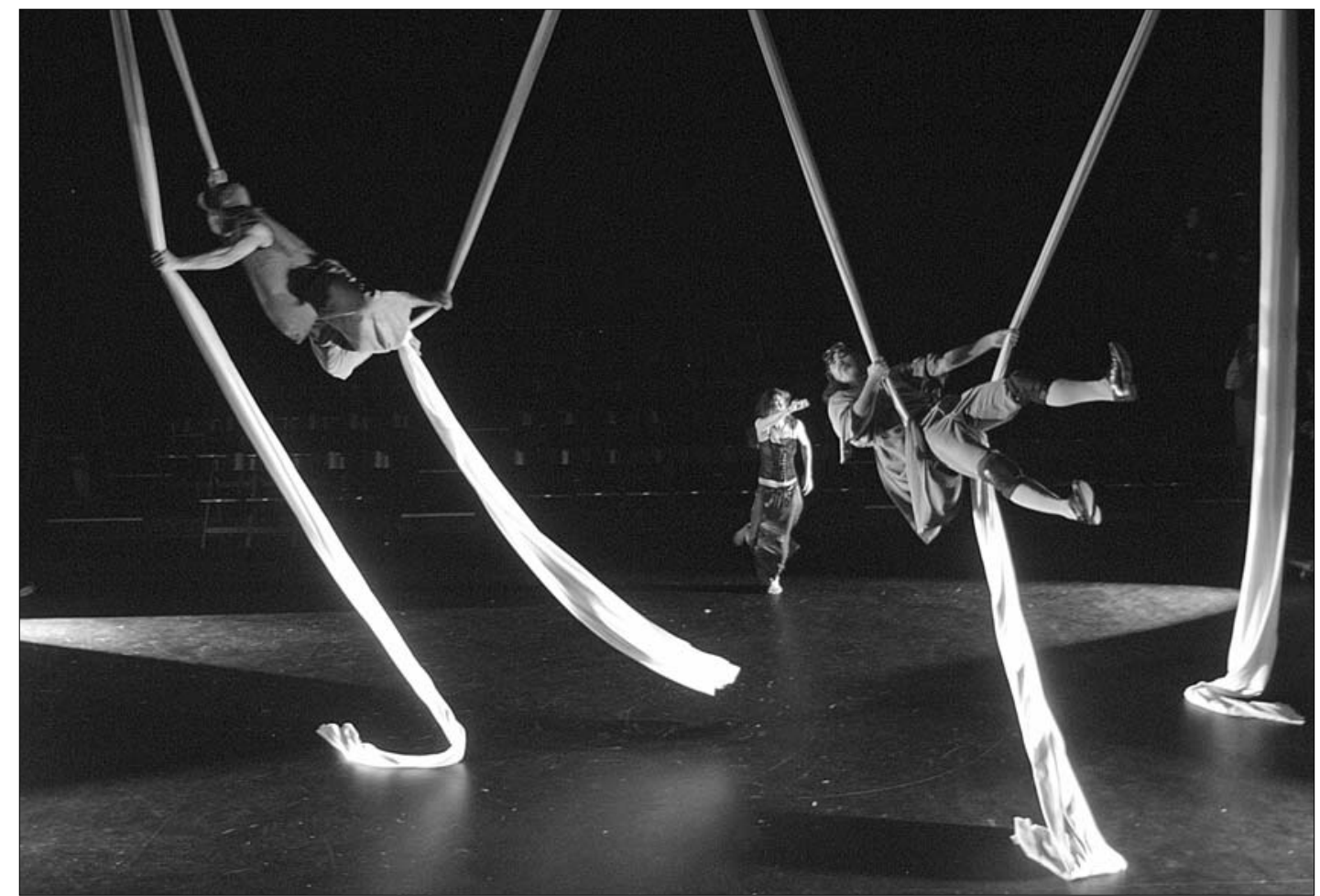

with in the UnPOSSESSED, in Republic of Dreams, and the Disappearance.

So that's how we interrelate. I think this might relate to the Jewish culture as much as anything else because the Jewish culture has never been a dominant culture. Jews have always had to find their culture amidst Christianity, or even Islam. I don't believe that one explores their culture in making the group that they're with explore it with them. I think it's very intimate.

Carlos is one of the strongest people I have ever met in my life. He is so strong that he is gentle and, for me, that was a shock beyond belief. Having been with fairly macho men who weren't American, and Americans who were 'correct', I hadn't faced that kind of purity of strength and kindness together in one human being. So, on meeting him, I wanted to get inside of him and really explore what all that was. It led me back to wanting to explore again who I was as a woman. In addition, he was really unformed because his work was uneven, untrained. He had a company, Diablo Mundo. It was a very important company in South America, and his brother, who recently died, was the lead
From the UnPOSSESSED.

Photo (above) by Robert Tobey, (below) by courtesy of Brandeis Theater Department.

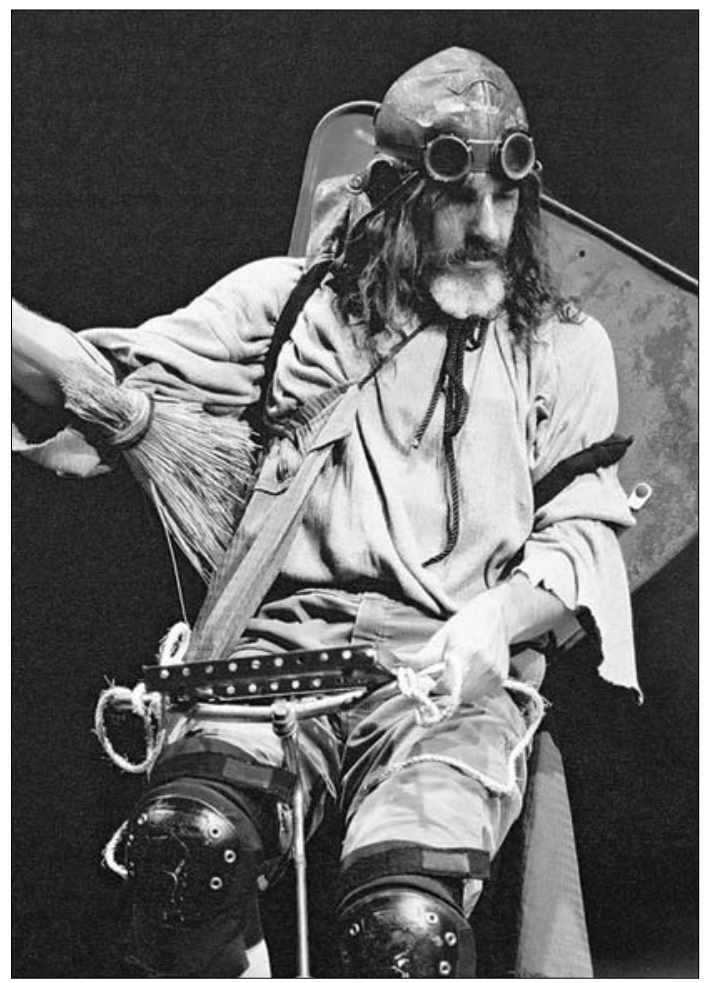


actor. I think that the combination of people in it pushed Carlos into producing.

When I met him, he had given up acting and didn't believe that he was an actor. I think I can say, after twelve years of working with him, he has now found himself as an actor - I mean really, where he puts himself totally into his work instead of remaining outside. I think his remaining outside was related to his experience in Argentina during the military period. He was very guarded in his work, not in his life. So, it's been a long process of training and opening, and opening, to find Carlos. And Carlos has found Carlos. It's astonishing.

It also indicates to me that, no matter how old you are - because Carlos and I were both forty when we started to work together - you can train and find yourself, and you work, no matter what your background is. I think that a lot of the things that are 'Carlos' are cultural things.

\section{Politics, Argentina, culture?}

Politics, definitely. Carlos was formed in the military period. His daughter-in-law was born in a jail, and he was in jail enough to know how not to get 'disappeared'. He actually had to leave Buenos Aires for a while so they couldn't catch him. It was horrific what happened. Our first conversation about it was two years after we met, and it was very painful. The early work in Diablo Mundo was related to that time but, when they needed to make the leap to the next thing, they couldn't do it as a group. This was one of the reasons he left and, I think, one of the reasons he found me - because he needed an outsider to be able to deal with himself. I'm an outsider.

An outsider in relation to him, or an outsider in relation to the United States?

Both, definitely. We consider ourselves outsiders, and the group considers itself to be cultural outsiders. I think that's true of all of us. Even if I say we're investigating culture, it's not like trying to grab 'Jewishness' or something. There is something outside. It's, like, 'How can I be that which has been insti- tutionalized, which has been fossilized, which has been co-opted? How can I be that?' I don't believe in organized religion, for instance. When my daughter was young my house was kind of kosher. I raised the kids at home in a Jewish way, and when my daughter was eleven she said she wanted to go get Bat Mitzvah-ed. I didn't belong to the synagogue, so I went to the Rabbi and said, 'I can't join the synagogue because I don't believe in organized religion.' We had a long talk about Judaism, and he allowed her to join. She went, and she joined, and she has now decided that she's going to become a rabbi. And I said, 'How are you going to deal with the organization or institution?'

Well, she has clearly chosen to fight from within. That's not my way. People here in America talk about us as European. The people who live outside always talk about us as American. This is part of the whole thing about Double Edge being outsiders.

That's interesting. I see you as American. I mean, the 'dust' is European, but the actual appropriation and working through is American. It could be nothing else.

I totally agree with you. We need some writing on that. I think it's starting to come out: there's some pioneer spirit here, something about the individual. . . .

Well, the Farm and its ethos suggest Emerson and Thoreau. It's the individual, it's the pioneer, the rural, the wilderness. It's the creation of the utopian community, but very much in an American sense of the word. It's not like the utopian communities of Europe. In fact, it seems strongly New England.

Yes, correct. And Carlos and I really identify with New England. That's the approach to culture that I am talking about. It's where you identify yourself, and that's part of the story. And then where you live is also part of the story. The other thing I found with Carlos is that he's an American - South American, but American. We share a lot of things that I don't share with Europeans. And magic realism is something we share. 


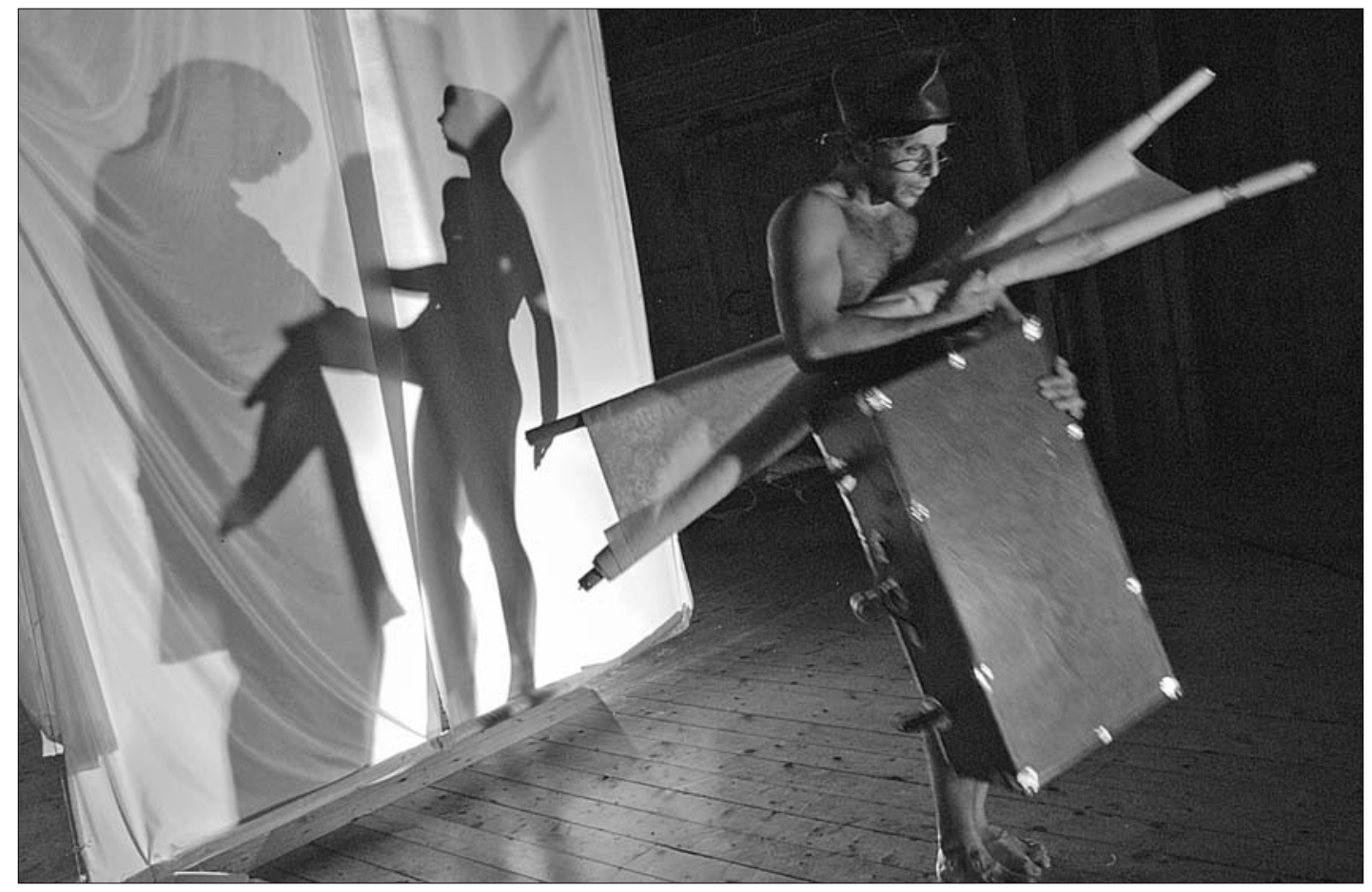

From Republic of Dreams. Photo: Robert Tobey.

Magic realism is characteristic of the Garden Cycle piece, the Don Quixote piece [the unPOSSESSED], in particular.

Yes, because we were actively working on it there. But in the Schulz piece, we were working with that, as well, in terms of the father and the father's world. Carlos and I worked on it for the Schulz piece probably more than anybody else.

I wanted to ask you which Schulz stories you used?

The story 'Spring' and the essay 'Republic of Dreams', primarily.

Which is where you get the title, of course. Well, this brings us to the whole question of process. You clearly work on the basis of improvisations. I think it's true to say that you work on free association. Improvisation is not necessarily based on texts: it can be a picture, an image, a sound, a piece of music. You work through various stages of improvisation at the point at which improvisation starts to become presentation. And it seems to me that you very much work on the idea of the development of the individual's imagination and the imaginary world in which this individual lives, and what this individual wants to explore in relation to himself or herself as a human being who is also a performer. Would that be a fairly accurate opening gambit?

Yes, it's great!

The dominant element of your work is the visual, which takes us to Kantor, but you have wonderful musical scores. Did everyone here come already playing an instrument?

Well, Scott [Halligan] is a professional cellist. Brian [Fairley] is a pretty professional pianist. Todd [Trebour] is an opera singer.

Todd is the blond man who played the violin at one point?

Yes, but his instrument is voice. Hayley's mother is a music teacher, so she was raised with instruments and different things. Matthew played the clarinet when he was young, and then he learned it again when he came here. Jeremy has learned accordion here. 
What about your interns? How long do they train here?

Three months, then, if they stay, they have to do three years of training. And, I would say, at this point, it takes another couple of years to become a real actor.

Well that, of course, brings up the issue of whether training ever stops.

It doesn't stop and, of course, the actors of the company are still training.

And the people who want to become associates. What do they do during those three years?

They do physical training and object training, and the objects are very important because the principle of our training is a person and 'the other'. And 'the other' can be an object - that's the easiest. Let's say they have to walk on spools, so they have to find their balance because the spool is greater than them. We love playing with objects, and we love training with them.

I get bored easily. So, when I started training, I would get bored. We found these spools and we started working with them. I really loved the way you could roll. And that was at the beginning of our training. I think that what I really like is an object that challenges the individual - something that they can't control; control is the worst possible thing for an artist. I'm not talking about discipline or responsibility, but control. Or, partner work is another approach, because you can't control a partner either. So, it's always the person and the 'other' until the person can create their own 'other', which takes many years and is basically what people here do.

Now we also do a lot of singing and a lot of instrumental work. Our old musical director loved making people who couldn't play music play music. That's how the music for the Quixote piece was done. Scott has been a really great new contribution because he's an amazing cellist. We didn't have the cello before in the Schulz piece. We added that, and I love what he's doing, and so does Hayley, so that's good. They work really well together.
In the first three months, the interns - who experience a microcosm - train physically for four hours a day and with objects and whatever else.

\section{Acrobatics?}

To a certain extent.

\section{So, plastic work?}

Yes, corporeal work. There's some yoga but, really, it's more about pushing them. People here run a lot. We're known all over this region: 'Ah, there goes Double Edge.' The actors really love running in the hills.

Running gives you stamina, among other things.

The training is partly about stamina and then, ultimately, about opening yourself up to physical metaphor.

\section{What do you mean by that?}

We're just discussing that with them because this second etude, which we call 'the middle part', is really about training beyond yourself to something performative. So you want to find not just, 'I'm on a spool,' but 'When I'm on a spool, who am I and where am I? What is the story of me on the spool?' So taking it from physical to physical metaphor, which is using archetypes, or stories, or music, or image. Like, 'Am I at war?' or 'Am I getting married?' or what?

And do you do much textual work with them? Are they asked to read a lot?

They are asked to read all the time. It's very important to me that people have a body of humanity to draw from, especially at their age, when they don't have much experience to draw on.

\section{So they read novels, poetry ... .}

They are asked to read everything that we have used as source material, and they're given a list of important theatre things, as well, that they could read. And literature. And the world. They're asked to read about anything that's important to them and not just make assumptions. 
Like, for example, they could read a book on Quakers?

Yes, exactly. Some of them respond to that more than others, of course, the same as with everything. The ones who don't respond to that usually don't do as well.

\section{Lots of singing?}

There's a lot of singing and a lot of instrument playing. Scott does the instrumental work with them and Brian does the singing work. Both of them, at the start, were extremely, let's say, 'rule-oriented'. They fought with me, and they won in the sense that they actually engaged in dialogue with me. Now they're really good musicians and need to see that the rules aren't what make them so. I think Scott is here because he wants something different, so he combines the rules with dialogue, and that's what is unique about us. I'm not really interested in nor do I know anything about - music, but I'm very interested in how the transitions work. Like, yesterday, we specifically worked on all of the Quixote music transitions before the performance because I was unsatisfied. They're really happy about that. Clearly, it was not just me who was unsatisfied.

They can work very much as teachers of the group, can't they? They can 'train' them to be musicians. The question I'm getting towards is: how much do you rely on professional teachers?

It's not like that, Maria, because when Brian came here, he was training with Justin [Handley], who wasn't a professional musician. He actually wanted to be a rock star. There is an answer to this.

\section{Self-training, as Barba does at the Odin?}

Yes. I think in Double Edge it might be a combination. For instance, we got professional tango dancers to train that tango we do in Republic of Dreams. We have Double Edge Tae Kwon Do here. Part of the training is that we have a master who has created a school for us, and we do that in the pavilion. We bring in masters more and more. Scott is a professional cellist. I am looking for mastery. I don't think Matthew will continue playing clarinet without really studying on a professional basis. On the other hand, his desire lies there. But less and less am I interested in someone plucking on an instrument or rasping out their words.

In the old days, we used to do it in more limited ways. I think it's the same as the individual and the group. It's the self-trained and the professional: they aren't in opposition, and they work together in Double Edge. So, for instance, Scott wasn't allowed to teach people until he learned Double Edge's method because we didn't want to teach people how to be a musician, or how to play an instrument. We wanted to teach people how to work musically in the theatre, and so he's been training with us for two years, and he does all the training. Now he knows. He's developing a really interesting new training. The same with Brian. Even though he was a professional, he was being taught, to his great consternation, by our rock star musical director, and it frustrated him enough to develop a way of training singing that was Double Edge. That's pretty much what we're doing. Several of the people - Hayley, Jeremy, Hannah [Jarrell] - led by my daughter, go to the New England Center for Circus Arts and do trapeze and other circus arts.

You have to learn how to do that without hurting yourself. That's where you need a professional.

Yes. We used to work a lot with ropes and we didn't know anything. Then, our rigger, who is from the New England Circus School - he fell in love with us - came and said, 'OK, I'm glad you guys didn't die, but you can't ever work like that again. You have to get this, and this, and this.' And we replaced everything. Now, Adam is in charge of all of that stuff, and he uses our rigger every time we don't know something. I believe in experts, and we want to combine what they know with what we want to do. 